\title{
Servitization in the automotive industry: How car manufacturers become mobility service providers
}

\author{
Felix Genzlinger \\ Ernst and Young \\ fgenzlinger@t-online.de \\ Leid Zejnilovic \\ Nova School of Business and Economics, Universidade NOVA de Lisboa \\ leid.zejnilovic@ novasbe.pt \\ Oscar F. Bustinza \\ Management Department, University of Granada \\ oscarfb@ugr.es
}

\section{One sentence summary:}

Automotive industry business models are changing the competitive landscape by developing innovative capabilities based upon collaborative methods of technology development.

\section{Summary:}

The automotive industry, as other manufacturing industries, has evolved from competing on discrete transactions to relational agreements with customers. 
While previous literature calls for further analysis of the observed heterogeneity found across servitized manufacturing industries, this paper contextualizes the analysis in the automotive industry.

Servitization follows a sequence of stages, from offering basic and intermediate services, to new business models based on the provision of advanced services to customers. As the advanced services are related to core competencies of the car manufacturers, complex collaborative arrangements are the primary market strategy choice. This paper demonstrates the challenges and opportunities related to such choices, over a set of internal and external categories and along the servitization journey.

Keywords: Servititization, service disruption, automotive industry, make-or-buy decisions.

J.E.L Codes: L22, O33.

\section{Acknowledgements:}

Leid Zejnilovic acknowledges financial support from Fundação para a Ciência e Tecnologia (UID/ECO/00124/ 2013) by LISBOA-01-0145-FEDER007722 and Social Sciences Data Lab, Project 22209. Oscar F. Bustinza acknowledges financial support from FEDER/Ministerio de Ciencia, Innovación y Universidades - Agencia Estatal de Investigación. Project ID: PGC2018101022-A-100.
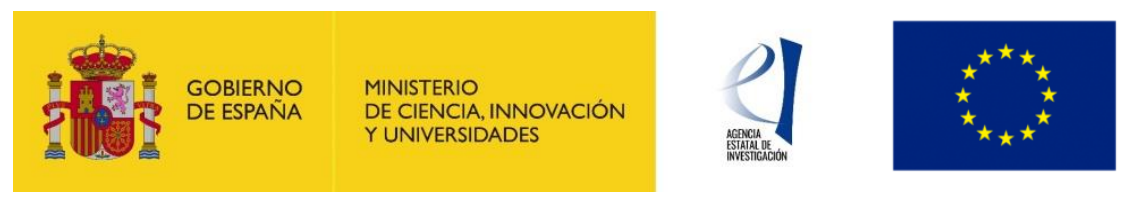

\section{Unión Europea}

Fondo Europeo

de Desarrollo Regional

"Una manera de hacer Europa" 


\section{Introduction}

The shift of manufacturing industries downstream the value chain, the servitization, started by the end of the 1990s as the manufacturers realized that services are more lucrative than products (Wise and Baumgartner, 1999). The transition towards services has changed traditional manufacturers' strategy that was traditionally based on vertical integration, superior products, and economies of scale to establish market dominant position. The traditional manufacturing strategy provided sustainable competitive advantage and generated scale barriers that deterred competitors. The new strategy for manufacturers, service competition, is based on different competitive dynamics (Cusumano et al., 2015). It rests upon the evolving nature of the relationship between manufacturer and buyer, which is increasingly notable over the last decades (Kamp, 2019). In the past, the sale also meant the end of the conversation between the two. Today, not the exchange of tangible goods, but intangible services like specialized skills, knowledge, and processes are central to customers' value creation (Coreynen et al., 2017). This is a strategic change in how firms create value, requiring them to continuously learn from and with consumers, and remain adaptive to their fast-changing needs to provide not only products, but valuable solutions.

New technologies enabled progressive digitalization throughout all industries, facilitating novel services and innovative business models (Gallouj et al., 2015). This transformation, named servitization, requires developing technology-enabled business models that facilitates the provision of customer knowledge-based services during the entire life-cycle of manufacturing products (Bustinza et al., 2018). Therefore, it imposed 
the need upon manufacturers to re-think their competitive advantages and differentiation strategies (Lafuente et al., 2017). This is a highly relevant exercise for different manufacturing industries as servitization strategy has been proved to have heterogeneous results according to the industry where these technology-based strategies have been implemented. For instance, Bustinza et al. (2019a) found that successful servitization strategies have different outcomes according to the collaborative method for developing service innovation selected, and the industry analyzed. To fill the research gap on the analysis of the industry heterogeneities founded in the servitization literature, our research aims to better understand the different stages of the servitization journey followed by a leading automotive manufacturer in developing servitization business models. Our analysis contributes to the understanding of the importance of establishing a successional pathway of servitization stages implementation for servitized manufacturers, a critical issue on the servitization debate (Baines et al., 2017; Parida et al., 2015; Visnjic et al., 2018).

Given the importance of servitization in the automotive industry (Opazo et al., 2018), this empirical research attempts to answer the following research question: What are the opportunities and challenges of creating and capturing value in the servitization process of a car manufacturer that is transitioning to a mobility service provider? To address this gap, this paper uses the model proposed by Gaiardelli et al. (2014) to classify the service offering of a traditional manufacturer, BMW, and assess the servitization process in the automotive industry over time. In addition, qualitative empirical research enables us to gain deeper insights into opportunities and challenges a manufacturer is facing along this transformation process, and how and when collaborative methods of developments are likely to occur. Beginning with a literature review and an industry contextualization, this 
paper follows by the description of and the results of qualitative research, and ends with a discussion of contributions for academics and practitioners.

\section{Theoretical background}

\section{Servitization}

Services are increasingly taking the lead in the global economy by enabling both wealth production and value-adding. While in most OECD countries, the service component of GDP has reached $70 \%$ of total gross value added and about 50 to $70 \%$ of employment, among traditional manufacturing companies, service offerings have usually been seen as a necessary evil (Perona et al., 2017). But in search of a closer customer relationship, higher returns, and additional growth opportunities, manufacturers of all kinds of industries have shifted their focus from simple products to holistic customer solutions (Davies et al., 2016).

The idea behind the servitization of manufacturing firms can be traced back to Levitt (1969), who reported a case concerning a salesman on tools, stating: "Last year, one million quarter-inch drills were sold not because people wanted quarter-inch drills but because they wanted quarter-inch holes.” This example illustrates the customers' focus on functionality rather than the product itself. Approximately two-thirds of manufacturing firms in developed countries have adopted a so-called servitization strategy (Vendrell-Herrero et al., 2017). Even though experts describe servitization as a Western phenomenon, China, which historically grew driven by the manufacturing power also noticed a sharp increase of GDP through services (Helo et al., 2017). The transformation is particularly notable in highly competitive markets with a strong need for differentiation and offering adaption to meet 
heterogeneous customer needs while exploiting economies of scale from high-volume production.

The literature distinguishes two strands of servitization (Green et al., 2017). The first strand, goods-dominant logic, uses services solely as an add-on to achieve an uninterrupted performance of a physical asset. The second strand, the service-dominant logic, places greater emphasis on customer's context. It focuses on co-created value attained by the customer when experiencing or using a physical product. Manufacturing firms are specifically focusing on providing advanced services, which can be defined as "a capability delivered through product performance and often featuring: relationship over extended lifecycle, extended responsibilities and regular revenue payments" (Baines and Lightfoot, 2013). Thus, it is not just about simply adding services. Customers want a full continuum of products and related services that play a key role in their core operations. Following this logic, the overall aim is to design a bundle of advanced services and products that incorporates the firm's and the customers' resources. By doing so, manufacturing companies show not just proof that they can build valuable products, but also that they know how to enable customers to get the most value out of them.

The spectrum from pure products to pure intangible services is quite wide-ranging, and in most cases, both extremes are involved to a certain extent. Tukker (2004) describes eight archetypical Product-Service Systems (PSS) or servitization business models classified in three distinct categories, from solely product-oriented to purely serviceoriented value creation. By offering product-oriented services, the manufacturer not only sells the product but also offers services that are needed during the use phase; for instance, maintenance contracts, financing schemes, or the advice and consulting services to enable 
the customer to most efficient use (Ziaee et al., 2018). Nevertheless, the core activity remains the sale of the physical product. Use-oriented services, like product leasing, renting, and sharing describe an offering without a shift in ownership of the product. The provider oversees maintenance, and the product can be used by more than one customer. The sale of the product is not the actual core activity, but the product remains a central part of the offer or its acquisition remains the respective long-term goal. With the third category of business models, result-oriented services, the customer solely enjoys the output of the product according to the level of use. The contract of the user and provider relies solely on the result, which determines the satisfaction of customers' needs.

When considering the role of technology in servitization, Porter and Heppelmann (2014) proposed that connected products are transforming competition. They argued that with falling costs of obtaining, processing, and transmitting information, technology is changing the way companies design products, but also services. Today, new technologies, mainly driven by the IoT, offer a unique possibility for companies to gain deep knowledge about their customers and their individual needs. Value creation can be much more effective if real-time information is flowing seamlessly between devices and is co-created by companies and customers. Enabled monitoring and control capabilities provide companies with an enormous amount of data about user preferences and their utilization with the products (Ceci and Masini, 2011; Gallouj et al., 2015). Through the efficient use of large volumes of data, more value can be derived from servitization. Consequently, digitalization not only supports the delivery of advanced services, but also the ideation and creation process (Gebauer et al., 2005). Therefore, digitization plays a key role in the 
service transformation and can be described as a strong servitization enabler (VendrellHerrero et al. 2017).

Digital business models have strong technology dependence. Strategic partnerships of manufacturers with KIBS providers represent a fast way for developing such business models through collaborative agreements. At the same time, these partnership may result in the loss of the customer relationship, hence decreasing the manufacturer's brand value. Therefore, KIBS providers need to be chosen and managed carefully (Bustinza et al., 2019b; Gomes et al., 2016). Furthermore, provision of services without any synergies with the core business may be wasteful, as it becomes questionable whether any competitive advantage is created or reinforced. Thus, developing service business is complex, with unpredictable and varied demands, where customers expecting immediate responses and high levels of customer service. To shed light on how manufacturers develop digital services business models, we explore the strategic change towards servitization and how it unfolds over time in an incumbent automotive industry firm, BMW, identifying the associated challenges and opportunities.

\section{Research Context and Methodology}

\section{Research Context: the automotive industry in disruption}

For many decades, automotive industry has been highly concentrated, where the incumbents held a stable position (Bailey, 2007). There has never been a real threat of substitutes because no other way of mobility allowed the same level of convenience and individual freedom. Due to OEM's strong market position, the bargaining power of suppliers has always been relatively low, and prices were dictated by the car manufacturers. 
Exorbitant capital investment needs and the OEMs' brand heritage have always represented high barriers that have kept away most of new entrants. For most of its existence, the automotive industry has followed a linear development path, with product improvement being the principal innovation activity for dealing with internal competition.

Over the years, car manufacturers have outsourced their production to an increasing extent, resulting in an enormous know-how shift to suppliers. Consequently, value added by manufacturers decreased to only $25 \%$ (Dmoch, 2017). The actual value that can be provided by the product itself is also tremendously lowered due to changing customer needs. The car is losing its position of a status symbol. At the same time, the preferences of new generations of mobility customers are shifting from owning to using a car. The customers want to use a car and enjoy individual mobility but without the downsides of vehicle ownership like parking costs, insurance, maintenance, etc. (Ross, 2014). In addition, once self-driving cars start entering the mobility market, we are likely to observe a growth in the supply of on-demand service vehicles that eliminate major service costs, like a cab driver. Mobility service offerings, such as carsharing, may gain importance for customers at the account of car ownership. These trends may weaken manufacturers' core business of selling cars. To deal with the future uncertainties, some OEMs resort to collaborative product development with KIBS providers, like Volkswagen with its strategic partnership with Uber. In these collaborations, OEMs may be degraded to only hardware suppliers, and lose the customer interface.

The above mentioned trends imply that the traditional manufacturers need to shift from their product-centric inside-out approach to a customer-centric outside-in approach. Additional service models besides product innovations represent an opportunity for OEMs 
to extend the product lifecycles and increase customer engagement (Bustinza et al., 2017). In order to further understand the transition to a customer-centric approach, this study explores opportunities and challenges along the servitization journey of a traditional car manufacturer. First, we collect secondary data on BMW's service portfolio, and apply a classification model to identify its servitization journey over time. Next, we conduct a qualitative research, to gain deeper insights into the perceived opportunities and challenges a traditional car manufacturer is facing in their exploration of becoming a future-proof mobility service provider.

\section{Data collection and analysis}

We construct BMW's service portfolio by using publicly available information from the company website and brochures. A cross-check with an authorized dealership ensures the reliability of the findings. Gaiardelli et al. $(2007,2014)$ used their PSS classification model to analyze a service portfolio of a truck manufacturer, and we apply it for classifying the service offering of a passenger car manufacturer. We collect information on 32 services offered by BMW, year of introduction, whether offered for free, the nature of transaction and offer orientation. Upon completion of the collection, one of the author worked together with an expert from the manufacturer to identify positions of the services relative to each other. To minimize the error due to subjective relative positioning, another expert from dealership has verified the positioning.

Upon the analysis of the services, we conduct five semi-structured interviews. We selected the interviewees according to the industry structure (Angwin et al., 2014). The automotive supply chain is not vertically integrated, but rather complex and fragmented 
(Gaiardelli et al., 2007). Car manufacturers do not directly own the product and service channels. Those are mainly outsourced to authorized dealers that are responsible for the product sales and the service operations. Even mobility services are usually performed by third party companies and just directed by the manufacturer. This implies that two different value chains need to be considered with dealers and mobility service providers covering most of the respective chain. Therefore, five interviews were conducted; two with sales managers from a well-established BMW dealership, and three interviews with BMW mobility service experts, two on the corporate side, and one working for DriveNow, BMW's European carsharing brand. In addition to the five semi-structured interviews, one short interview was done with a BMW engineer to get some insights on technical requirements. The list of the interviewees is presented in table 1. All interviews were conducted via phone and transcribed in German by a co-author of this paper.

----Insert Table 1 about here----

We apply a directed approach content analysis to analyze the interviews (Hsieh and Shannon, 2015). Using the existing theory, the authors identified initial coding categories and used them to group relevant interview questions. All transcripts were reviewed carefully, highlighting the text that appeared to describe opportunities or challenges related to servitization. The highlighted text was coded using the predetermined categories, wherever possible. The key findings were clustered and sorted in a matrix constructed to provide a holistic overview.

\section{Analysis of the service-portfolio of a traditional OEM \\ Classification of the service-portfolio}


To analyze the servitization process, we first classified BMW's current service portfolio. The model by Gaiardelli et al. (2014) combines three major classification dimensions. The first dimension is the "orientation of the offering" based on Tukker et al. (2004), distinguishing between product-oriented, use-oriented and result-oriented offerings. Second dimension is the "nature of interaction" between provider and customer ranging from a simple transaction to a constant relationship in which information is flowing seamlessly to enable co-creation of the offering. This dimension also entails different ways to price the service: "from a markup for labor and parts (transaction-based approach), to a fixed price covering all services over an agreed period (relational approach), and the risks taken by the provider dramatically increases" (Lay, 2014). The third dimension is the "offering focus," moving from ensuring the availability and functionality of the product (vehicle) to enhancement and optimization of the actual process (moving).

The classification of the services that BMW, its dealers, and mobility service providers are offering is visually presented in Figure 1 and Table 2. Most of the identified service offerings are product-oriented, aiming to enhance the features of the vehicle and to support customers' operations during the entire product lifecycle. Several of these services entail a high level of customization, like the extension of the product warranty or individual financing schemes. They are also offered as packages linking related services together, to increase customer value and also provider's revenue. An example would be the pick-up and delivery service in combination with maintenance services at the dealership. These examples demonstrate the company's efforts to design linked services to align its offering with individual customer needs. Most of the product-oriented services are transactionbased, characterized by low interaction intensity and few touchpoints along the customer 
journey. BMW, like other OEMs, has also tried to expand its relationship-based services with offerings like remote monitoring diagnostics or corporate credit card services. These services are characterized by a higher number of customer touch-points, offering an opportunity for the manufacturer's brand to stay more relevant along the product lifecycle.

----Insert Figure 1 and Table 2 about here----

Most of the product-oriented services are charged and represent a major source of revenue for the manufacturer and its dealers, up to $50 \%$ of the total profit. Besides these product-oriented services, BMW has recently expanded its service portfolio beyond product ownership. Use-oriented services like leasing or renting enable product offerings without a switch in ownership. New innovative business concepts, like carsharing, go one step further by focusing on the use of the product while making it available to a larger number of people, significantly increasing the efficiency of the product's use. Such innovative services are usually provided by third-party companies, like the carsharing provider DriveNow in the case of BMW. A joint venture between BMW and the car rental company Sixt, since 2011, DriveNow is offering Europe-wide shared and on-demand mobility services. BMW is working on the third level of Tukker's classification, the result-oriented services. In 2016, the company invested in the California-based carpooling app called "Scoop," and is planning to implement these services under their fully owned mobility brand ReachNow with which they are already beta testing an offering in the area of ridesharing in Seattle, USA. The development of the service offering over time, visualized in Figure 2, shows clearly that BMW's services have evolved from a strong productorientation to a recently greater focus on the actual process. 


\section{Findings}

Figure 1 unambiguously shows that BMW's service portfolio mainly consists of productoriented services for after-sales revenue generation. About 22 of the 32 identified service offerings are product-oriented, representing almost $70 \%$ of the total service portfolio. In addition, the majority of these services are transaction-based, strongly product-centric, and with relatively low influence on customer engagement. Nevertheless, over the last years, BMW has expanded its use-oriented services which now account for about $25 \%$ of the service portfolio. Especially new innovative business models, namely DriveNow, ReachNow, and ParkNow are providing customer value without a switch in product ownership and the respective downsides. Also, use-oriented services exclusively for electric vehicles are intended to compensate for disadvantages of the new engines like their limited reach. Furthermore, the study shows that BMW is investing in result-oriented services like carpooling and ridesharing (McFarland, 2017).

There is an agreement among experts that the prevalent disruption will lead to a decline of the automotive industry, and an accelerated growth in the personal mobility market (Delhi, 2016). This development shows customers' willingness to spend money on personal mobility even if buying cars will not be a prerequisite anymore. But OEMs can only benefit from this change if they start thinking differently and adapt to customers' changing needs. The analysis of BMW's service portfolio indicates that the company has recognized the growing importance of adding services that go beyond product ownership providing value-in-use. As discussed earlier, the evolving technology and changing customer demands are both forcing and enabling OEMs to think beyond product innovation 
and use servitization as a strategic option to stay relevant in customers' lives as well as competitive in the market. Nevertheless, traditional after-sales services focusing on the reliability and availability of the products still represent a major source of revenue for the manufacturers and particularly their dealers.

Based on the findings at BMW, Figure 3 is visualizing the servitization journey traditional car manufacturers are going through. Historically, they have grown out of product-focused business-expanding value creation through ongoing product innovations. Over time, car manufacturers have added product-oriented after-sales services to increase customer value and generate further revenue after purchase. These also enable the manufacturers to stay closer to the customers over the product lifecycle. These kinds of services represent a significant revenue source and need to be expanded to obtain product value. The third stage of the journey is the offering of mobility services where value-in-use is generated without any switch in ownership. These represent an opportunity for providers to establish strong customer relationships with more constant interaction. The third step embodies the biggest and most challenging one of the journey - a game-changer demanding entirely new business models in the automotive industry.

----Insert Figure 3 about here----

\section{Opportunities and challenges along the servitization journey}

The interview analysis resulted in a set of findings identified as opportunities and challenges along the servitization journey (see Figure 4), elaborated in this section.

\section{Customer relationship}


The sale of the product has a very transactional character, which may be a limiting factor for dealership interested in steady customer relationships. Services offer an opportunity for the dealerships to overcome such limitations, enabling them to stay more connected to the customers over the lifecycle of a vehicle, filling the gap between product purchases. For example, packages like "BMW Service Inclusive," usually sold in a bundle with a new vehicle, can create lock-in effects that tie customers to the dealerships (Dealer2). Relatively high prices maintained by the authorized dealers impose the necessity of high customer service satisfaction, to prevent customers' backing out along the journey. "The service business is very complex, and the customer can hardly assess how much a service is worth in Euros" (Dealer1). Therefore, sales representatives need to have the ability to make the customers get a feeling of premium care. "Services are the face of the dealership" and "like a reputation of a restaurant's kitchen" (Dealer1). Mobility services offer a way to address completely new customers and do so with a more continuous interaction.

The shift in customer needs is obvious when one looks into the typical customers; the average BMW driver in Europe is about 53 years old, and the average DriveNow user is in his early thirties. It does not surprise, therefore, the BMW's decision to invest in a new and more innovative brand image, like DriveNow, that shows synergies with the mother brand in terms of quality and trust but combined with the openness for rethinking mobility (BMW1). The character of the sub-brand also influences the image of the mother brand creating positive backward synergies (BMW2). Also, the consulted experts assume a strong marketing effect that could influence users of DriveNow to buy a BMW at a later stage in life. 
In general, with mobility services, the relationship becomes substantially closer. The provider has a chance to monitor and continuously analyze how the customer is using the product and adapt the offering to provide the highest possible value (Drive1). Although automation and machine-interfaces are instrumental in the provision of mobility services, one should not disregard the importance of customer service and the role of human interaction in building the convenience and the customer satisfaction. New needs like availability and convenience represent a major challenge that asks for a reinterpretation of brand premium (BMW1).

Even though the relationship is becoming more constant, it is losing the emotional component and reduces to a rational choice when satisfying the need to move from one point to another. As a consequence, another substantial challenge arises, the lack of care when handling the vehicles. This challenge is important because "the customer experience is not only determined by the provider but also immensely influenced by the behavior of other users the company can hardly impact" (BMW2). If a vehicle is messed up by previous users, it can annoy the subsequent customer. Educating people to pleasant usage without scaring them away with harsh penalties is a difficult undertaking (BMW2).

\section{Technology and customer data}

Digitalization is often described as an enabler of servitization (Vendrell-Herrero et al., 2017), which is also the case for most of the services in the automotive industry. New offerings like the "BMW Teleservice" enable real-time interaction of vehicle and service provider, expanding traditional diagnostic offerings. Also features like the online set-up for service appointments can increase convenience for the customer but also organizational 
efficiency of the dealership. Another important opportunity that comes with progressive digitalization is the huge amount of data that can be gathered from customers. More personal relationships can be created by collecting and storing personal data, like customers' favorite football club, for instance. Salespersons may make the use of the information to get closer to the customer and create emotional relationships. Also, sales promotions can be adapted to the known or predicted individual customers' needs. For instance, by constantly monitoring tires wear, dealers can communicate offerings the customer needs, exactly when he needs them (Dealer2). Email as a new way of interaction enables service providers like dealers to communicate promotions faster and at much lower costs (Dealer1). To avoid legal issues, companies need to follow changing data privacy laws and adapt processes if necessary. The interviewees also point out that efficient data management is necessary to capture the value out of these new opportunities (Dealer1, Dealer2).

A major downside that comes with new technologies is the threat they pose to traditional services. Disruptive innovations, e.g. for oil change, can make service offerings obsolete and eliminate important dealers' revenue sources. Also extending service intervals resulting from longer technology durability are diminishing the total number of after-sales services performed (Dealer2). In terms of mobility services, business models like carsharing were not even possible without the real-time flow of data between the involved devices. The connectivity of the car enables the localization of the vehicle and the user, the interaction between them, and hence the co-creation of value. By constantly analyzing customer behavior through the usage data, the offering can be highly personalized (Eng1). For example, the fleet management at DriveNow constantly analyzes customer behavior to 
find ways to increase the vehicles' availability. By getting a sense of time-dependent availability needs, for instance, in city areas versus at the airport at any given moment, the provider can take actions and influence vehicle coverage to satisfy the users' demand.

Another big challenge that comes with customer data is the need for transparency. Companies like DriveNow are constantly updating data regulations and trying to communicate them to their customers. Nevertheless, they know that a majority of customers do not check new updates thoroughly, even if they may claim to care about their data security. Making the updates obvious and easy to understand is difficult (Drive1). The progressive digitalization represents a big challenge for traditional OEMs like BMW by asking for a rethinking of business. They need to learn how to act in a completely new and fast-changing environment, the one where it is sometimes allowed to make mistakes (BMW1, BMW2). Service development cycles are much shorter than new car development cycles. BMW needs to "learn to also start with beta versions or MVPs and improve the most over time" (BMW1). A major threat comes from the new entrants that are born digital and more familiar with this agile environment (BMW1).

\section{Organizational change}

For dealers, services represent a major source of profit. The interviewed managers feel certain that sales representatives are fully aware of the relevance of selling auxiliary services besides the products. However, the intangibility of services makes it sometimes difficult for customers to assess exact value for money. Therefore, sales personnel need to be consistently coached to develop both soft and technical skills to make sure they communicate service value effectively to the customer (Dealer1). Another big challenge is 
the organizational separation of product and service sales. The product and service salespersons' compensation is solely dependent on their performance in terms of product or service sales, respectively. Consequently, "both are strongly focused on their business, separately, and rarely cooperating to provide the customer with the right solution" (Dealer2). Promoting collaboration could boost product and service sales.

Mobility services are causing internal conflicts. The experts describe a resistance, especially among older colleagues who lack the understanding why a company like BMW that has focused on production excellence for centuries now should invest in mobility services. Some of them are even afraid of cannibalization of the core business (BMW2). The challenge here is to make clear that "it is not a question of either/or" (BMW1). Quite the contrary, it helps to address more customers, diversify the overall offering and enable sustainable future growth. The expert BMW1 mentions an example from the newspaper industry, where the expansion to digital channels enables new innovative ways of interaction instead of to cannibalizing the traditional business. Currently, product sales are still significantly outperforming mobility services in terms of revenue and profit. Nevertheless, internal stakeholders need to be convinced of the relevance of thinking beyond product innovation and be more open to this new way of doing business. Such radical changes in structure but also company culture require time and determined management (BMW1).

\section{Competition}

Even though the automotive market is highly concentrated and characterized by high entry barriers, the service market has always been a sub-market that could be entered more easily 
than the hardware business because of lower financial investment needs (Dealer1). Independent service providers have always represented a threat, especially for the dealers, challenging them with relatively low prices. BMW's brand represents a great opportunity for dealers to overcome this competition. Usually, new car buyers want a premium service for their premium products. They trust the manufacturer in ensuring the best service quality (Dealer1, Dealer2). Over time, manufacturers and dealers have created services like warranty packages or leasing contracts that leave customers no other choice than let aftersales services be done at authorized dealerships (Dealer1). Furthermore, dealers are always trying to expand their offering to meet customer needs. For instance, "in the beginning of this year, the number of car break-ins in Frankfurt had increased dramatically. The dealer recognized an opportunity and collaborated with an established alarm equipment provider to create an offer for an affordable car alarm system. So, they tried to address the acute fears and needs of their customers" (Dealer2). The experts state that other services like pick-up and delivery, as well as the discussed personal relationship with the customers, offer them an opportunity to provide special customer experience and differentiate themselves from the cheaper competition (Dealer1, Dealer2). Also, increasing competition among mobility services represents a great challenge. As discussed earlier, the low entry barriers enable an immense number of new entrepreneurial players to enter the mobility market.

These companies are "born digitally, are much more agile, and they blazingly fast conquer customer interfaces" (BMW1). Even strategic alliances with these new players involve a great danger of losing customer contact and getting degraded to simple hardware suppliers (BMW1, Drive1). Nevertheless, car manufacturers have grown complementary 
assets that are hard to copy, like their hardware development expertise, brand value and trust of their customers, as well as financial resources that allow them independence of the external cash sources. With their own funds, the manufacturers can invest in or acquire innovative startups and learn from them (BMW1). Besides that, there is and will be a distinct need for vehicles, even for competitors like Uber (Drive1). Therefore, "if OEMs could become more agile with their service offerings besides the hardware business, they have a chance to sustain a competitive advantage also towards the new competitors" (BMW1).

\section{Profitability}

In terms of product sales, the dealership acts as a retailer, buying the car from the manufacturer at a discounted price to sell it to the end customer. However, because price negotiations with the end consumer diminish profit margins to almost zero, dealers fully rely on the high-margin services. But, there is a concern about the future profitability for the dealers. As already described, authorized dealers are charging higher prices than competitors like independent repair shops. The increase in product complexity shifts the costs and final prices for the end consumer upwards (Dealer1). The most price-sensitive are the used vehicle customers, who prefer cheaper competitors over authorized dealers. Furthermore, the predicted decrease in product ownership is likely to diminish the number of services sold. As fewer cars are driving around, there will be less need for after-sales services. In addition, the rise of the electric cars is likely to challenge the traditional service business: "Those require totally different maintenance services and less care in general" (Dealer2). 
The mobility services providers experience challenges in making money out of their services. Even though these offerings address new customer groups and have the potential to be used by more people, it is unambiguously clear that the revenue per customer is much lower than the revenue from the product sales. Besides that, when entering a new market, e.g., a new city, business models like carsharing require a big up-front investment. The investment includes the costs of the fleet, but also expensive marketing campaigns that are required to captivate people's attention and educate them on the usage of these new services (BMW1). In addition, DriveNow is facing a poor infrastructure in many cities they have entered, like the shortage of parking space. Convincing the respective city council to invest or allow investment in infrastructure is often a difficult and exhausting undertaking (Drive1). These challenges may help in explaining the 2 million Euros financial loss of the carsharing provider in 2016 (BMW Group, 2016).

The mobility service business has a distinctive profit-risk because the product "solely generates revenues when it is used" (BMW2). When selling a product or other use-related services, like leasing, the profit-risk is only present until the purchase transaction or the initiation of the service. The pay-per-use approach is characterized by strong revenue fluctuations, low success measurability and, consequently, poor profit predictability (BMW2).

The challenges and opportunities discussed above (and summarized in Figure 4) lead to the major changes that can be expected along the servitization journey in the automotive industry ( see Figure 5).

----Insert Figure 4 and Figure 5 about here---- 


\section{Concluding remarks}

The paper contributes to unveiling the heterogeneities found in the servitization literature related to industry context (Bustinza et al., 2019a), offering insights on the servitization process of a traditional car manufacturer. We evidence the different stages in the servitization journey as the manufacturers develop more complex result-oriented relationships with customers over time (Baines et al., 2013; 2017). As new offerings go beyond core competencies of the manufacturer, complex collaborative arrangements are often the preferred market strategy. The manufacturer finds the service business much more complex and characterized by more uncertainty compared to their core businesses. While allowing generating additional revenue between product purchases, mobility services are also opening entirely new customer groups that were previously out of the product business reach. Progressive digitalization is considered as the enabler of the development, but in fact, it is shifting the technology from the periphery, business-enabler, to the core of the business. On the flip side, the servitization in the industry seems to be weakening entry barriers and forces traditional OEMs to rethink their way of doing business. While seminal research from Vandermerwe and Rada (1988) highlighted the strategic importance of servitization to lock-out competitors, the final stage of servitization, that is the provision of advanced services (Baines et al., 2017) or result-oriented services (Tukker, 2004), could diminish product entry barriers established unless the manufacturers keep a part of the service revenue stream that guarantees continuous product update. Therefore, new product entry barriers may be established through the updated information and revenues generated by the new service business models. 


\section{Managerial implications}

The interviews with the industry experts suggest that the product- and after-sales service businesses will be affected by the great disruption ahead. Decreasing private ownership will downsize the market, thus forcing some players to exit. Due to the high demand for product information, the offline retail offered by the dealers will stay relevant because customers want to experience the car to the fullest before making a purchase decision. However, only the big providers have a good chance to survive because they have the resources to react to changes like the rise of electric mobility, while others will struggle to afford essential transitions. Additionally, customer service satisfaction and free-of-charge services will become more and more important to keep customers close.

The big shift from pure product manufacturers to providers of mobility as a service will require radical changes. Traditional car manufacturers have the resources and capabilities to successfully enter the new market of mobility services. Although the product business is likely to keep playing an important role in the future, as vehicles are still needed to offer mobility services, the manufacturers need to deal with new technologies and implement them into their products to enable the new service offerings. In the mobility service market, as technology standards set in, it is expected to observe shake offs of inefficient firms and the concentration of smaller firms that seek to optimize the cost and augment thin profit margins. The shift towards mobility as a service is going to take time, and the global demand for cars is expected to continue to grow in the near future. Hence the necessity for manufacturers to develop an ambidextrous organization (Duncan 1976, Raisch et al., 2009), maintaining focus on the core business and product improvements related innovation activity, but also exploring new business segments. This paper shows that 
servitization of the whole industry is a threat but at the same time a great new opportunity for established manufacturers. The OEMs that manage to transform to agile, adaptive, useoriented service-development organizations, and grow capabilities to engage in collaboration with KIBS providers, may be able to shape the mobility of tomorrow.

\section{Implications and further research}

Key findings obtained in this study reinforce the importance of servitization as a strategic option, especially in markets that are facing major disruptions, like the automotive industry. The analysis reveals relevant insights into opportunities and challenges of the servitization strategy that can help companies to enable sustainable growth through customer centricity and progressive technology usage. The current research reveals the need for further theory development regarding changing industry factors that need to be considered to guarantee strategic success. Validating this study's results with quantitative methods, like questionnaires, and reaching out to a larger number of respondents and other companies would increase the reliability of the results. Further research efforts should be directed towards the particularities of the advanced services provision. Also, to enable a more general perspective, this analysis should be expanded to other manufacturing firms. 


\section{References}

Angwin, D. N., Mellahi, K., Gomes, E., \& Peter, E. (2016). How communication approaches impact mergers and acquisitions outcomes. The International Journal of Human Resource Management, 27(20), 2370-2397. doi: $10.1080 / 09585192.2014 .985330$

Bailey, D. (2007). Globalization and restructuring in the auto industry: the impact on the West Midlands automobile cluster. Strategic Change, 16(4), 137-144. doi: $10.1002 /$ jsc.791

Baines, T., Ziaee Bigdeli, A., Bustinza, O. F., Shi, V. G., Baldwin, J., \& Ridgway, K. (2017). Servitization: revisiting the state-of-the-art and research priorities. International Journal of Operations \& Production Management, 37(2), 256-278. doi: 10.1108/IJOPM-06-2015-0312

BMW Group (2016). Annual Report 2016: A New Era Begins. Available at: https://www.bmwgroup.com/content/dam/bmw-groupwebsites/bmwgroup_com/ir/downloads/en/2016/BMW_GB16_en_Finanzbericht.pdf.

Bustinza, O. F., Vendrell-Herrero, F., \& Baines, T. (2017). Service implementation in manufacturing: An organisational transformation perspective. International Journal of Production Economics 192. 1-8. doi: 10.1016/j.jpe.2017.08.017.

Bustinza, O. F., Vendrell-Herrero, F., Gomes, E., Lafuente, E., Opazo-Basáez, M., Rabetino, R., \& Vaillant, Y. (2018). Product-service innovation and performance: unvealling the complexities. International Journal of Business Environment, 10(2), 95-111. doi: 10.1504/IJBE.2018.095819 
Bustinza, O. F., Lafuente, E., Rabetino, R., Vaillant, Y., \& Vendrell-Herrero, F. (2019a). Make-or-buy configurational approaches in product-service ecosystems and performance. Journal of Business Research, In Press. doi: 10.1016/j.jbusres.2019.01.035

Bustinza, O. F., Gomes, E., Vendrell- Herrero, F., \& Baines, T. (2019). Product-service innovation and performance: the role of collaborative partnerships and R\&D intensity. $R \& D$ Management, 49(1), 33-45. doi: 10.1111/radm.12269

Carlborg, P., Kindström, D., \& Kowalkowski, C. (2014). The evolution of service innovation research: a critical review and synthesis. The Service Industries Journal, 34(5), 373-398. doi: 10.1080/02642069.2013.780044

Ceci, F., \& Masini, A. (2011). Balancing specialized and generic capabilities in the provision of integrated solutions. Industrial and Corporate Change, 20(1), 91-131. doi: $10.1093 /$ icc/dtq069

Coreynen, W., Matthyssens, P., \& Van Bockhaven, W. (2017). Boosting servitization through digitization: Pathways and dynamic resource configurations for manufacturers. Industrial Marketing Management, 60, 42-53. doi:10.1016/j.indmarman.2016.04.012

Cusumano, M. A., Kahl, S. J., \& Suarez, F. F. (2015). Services, industry evolution, and the competitive strategies of product firms. Strategic Management Journal, 36(4), 559575. doi: $10.1002 / \mathrm{smj} .2235$

Davies, A., Brady, T., \& Hobday, M. (2006). Charting a path toward integrated solutions. MIT Sloan Management Review, 47(3), 39-48. 
Delhi, S. I. N. (2016). Automotive revolution \& perspective towards 2030. Auto Tech Review, 5(4), 20-25. doi: 10.1365/s40112-016-1117-8

Dmoch, T. (2017). What Is Driving the Disruption in the Automotive Sector? Capgemini Consulting. Available at: https://www.capgemini.com/consulting/2017/03/what-isdriving-the-disruption-in-the-automotive-sector/.

Duncan, R. (1976). The ambidextrous organization: Designing dual structures for innovation. Killman, R. H., L. R. Pondy, and D. Sleven (eds.) The Management of Organization. New York: North Holland. 167-188.

Gaiardelli, P., Resta, B., Martinez, V., Pinto, R., \& Albores, P. (2014). A classification model for product-service offerings. Journal of cleaner production, 66, 507-519. doi:10.1016/j.jclepro.2013.11.032.

Gaiardelli, P., Saccani, N., \& Songini, L. (2007). Performance measurement of the aftersales service network-Evidence from the automotive industry. Computers in Industry, 58(7), 698-708. doi:10.1016/j.compind.2007.05.008.

Gallouj, F., Weber, K. M., Stare, M., \& Rubalcaba, L. (2015). The futures of the service economy in Europe: A foresight analysis. Technological Forecasting and Social Change, 94, 80-96. doi:10.1016/j.techfore.2014.06.009.

Gebauer, H., Fleisch, E., \& Friedli, T. (2005). Overcoming the service paradox in manufacturing companies. European Management Journal, 23(1), 14-26. doi:10.1016/j.emj.2004.12.006. 
Gomes, E., Barnes, B. R., \& Mahmood, T. (2016). A 22 year review of strategic alliance research in the leading management journals. International Business Review, 25(1), 15-27. doi: 10.1016/j.ibusrev.2014.03.005

Green, M. H., Davies, P., \& Ng, I. C. (2017). Two strands of servitization: A thematic analysis of traditional and customer co-created servitization and future research directions. International Journal of Production Economics, 192, 40-53. doi: 10.1016/j.ijpe.2017.01.009

Helo, P., Gunasekaran, A., \& Rymaszewska, A. (2017). Designing and managing industrial product-service systems. Cham: Springer.

Hsieh, H. F., \& Shannon, S. E. (2005). Three approaches to qualitative content analysis. Qualitative health research, 15(9), 1277-1288. doi:10.1177/1049732305276687.

Kamp, B. (2019). Restructuring for service business development: insights from a machine tool manufacturer. International Journal of Business Environment, 10(4), 281-305. doi: 10.1504/IJBE.2019.101643

Lafuente, E., Vaillant, Y., \& Vendrell-Herrero, F. (2017). Territorial servitization: Exploring the virtuous circle connecting knowledge-intensive services and new manufacturing businesses. International Journal of Production Economics, 192, 1928. doi: 10.1016/j.ijpe.2016.12.006

Levitt, T. (1969). The marketing mode: Pathways to corporate growth. McGraw-Hill. McFarland, M. (2017). BMW plans for a future where nobody buys cars. CNN Tech. Available at: http://money.cnn.com/2017/05/24/technology/bmw-seattlereachnow/index.html. 
Opazo-Basáez, M., Vendrell-Herrero, F., \& Bustinza, O. (2018). Uncovering productivity gains of digital and green servitization: implications from the automotive industry. Sustainability, 10(5), 1524. doi: 10.3390/su10051524

Parida, V., Sjödin, D. R., Lenka, S., \& Wincent, J. (2015). Developing global service innovation capabilities: How global manufacturers address the challenges of market heterogeneity. Research-Technology Management, 58(5), 35-44. doi:

$10.5437 / 08956308 \times 5805360$

Perona, M., Saccani, N., \& Bacchetti, A. (2017). Research vs. practice on manufacturing firms' servitization strategies: A gap analysis and research agenda. Systems, 5(1), 19. doi:10.3390/systems5010019.

Porter, M. E., \& Heppelmann, J. E. (2014). How smart, connected products are transforming competition. Harvard Business Review, 92(11), 64-88.

Raisch, S., Birkinshaw, J., Probst, G., \& Tushman, M. L. (2009). Organizational Ambidexterity: Balancing Exploitation and Exploration for Sustained Performance, Organization Science, 20:4, 685-695

Ross, D. (2014). Millennials don't care about owning cars, and car makers can't figure out why. Fast Company. Available at: https://www.fastcompany.com/3027876/millennials-dont-care-about-owning-carsand-car-makers-cant-figure-out-why.

Tukker, A. (2004). Eight types of product-service system: eight ways to sustainability? Experiences from SusProNet. Business Strategy and the Environment, 13(4), 246260. doi: $10.1002 / \mathrm{bse} .414$ 
Vendrell-Herrero, F., Bustinza, O. F., Parry, G., \& Georgantzis, N. (2017). Servitization, digitization and supply chain interdependency. Industrial Marketing Management, 60, 69-81. doi:10.1016/j.indmarman.2016.06.013.

Vendrell-Herrero, F., Gomes, E., Bustinza, O. F., \& Mellahi, K. (2018). Uncovering the role of cross-border strategic alliances and expertise decision centralization in enhancing product-service innovation in MMNEs. International Business Review, 27(4), 814-825. doi: 10.1016/j.ibusrev.2018.01.005

Visnjic, I., Neely, A., \& Jovanovic, M. (2018). The path to outcome delivery: Interplay of service market strategy and open business models. Technovation, 72, 46-59. doi: 10.1016/j.technovation.2018.02.003

Ziaee Bigdeli, A., Bustinza, O. F., Vendrell-Herrero, F., \& Baines, T. (2018). Network positioning and risk perception in servitization: evidence from the UK road transport industry. International Journal of Production Research, 56(6), 2169-2183. doi:

10.1080/00207543.2017.1341063 
Figure 1. BMW services classification, using PSS classification model by Gaiardelli et al. (2014).
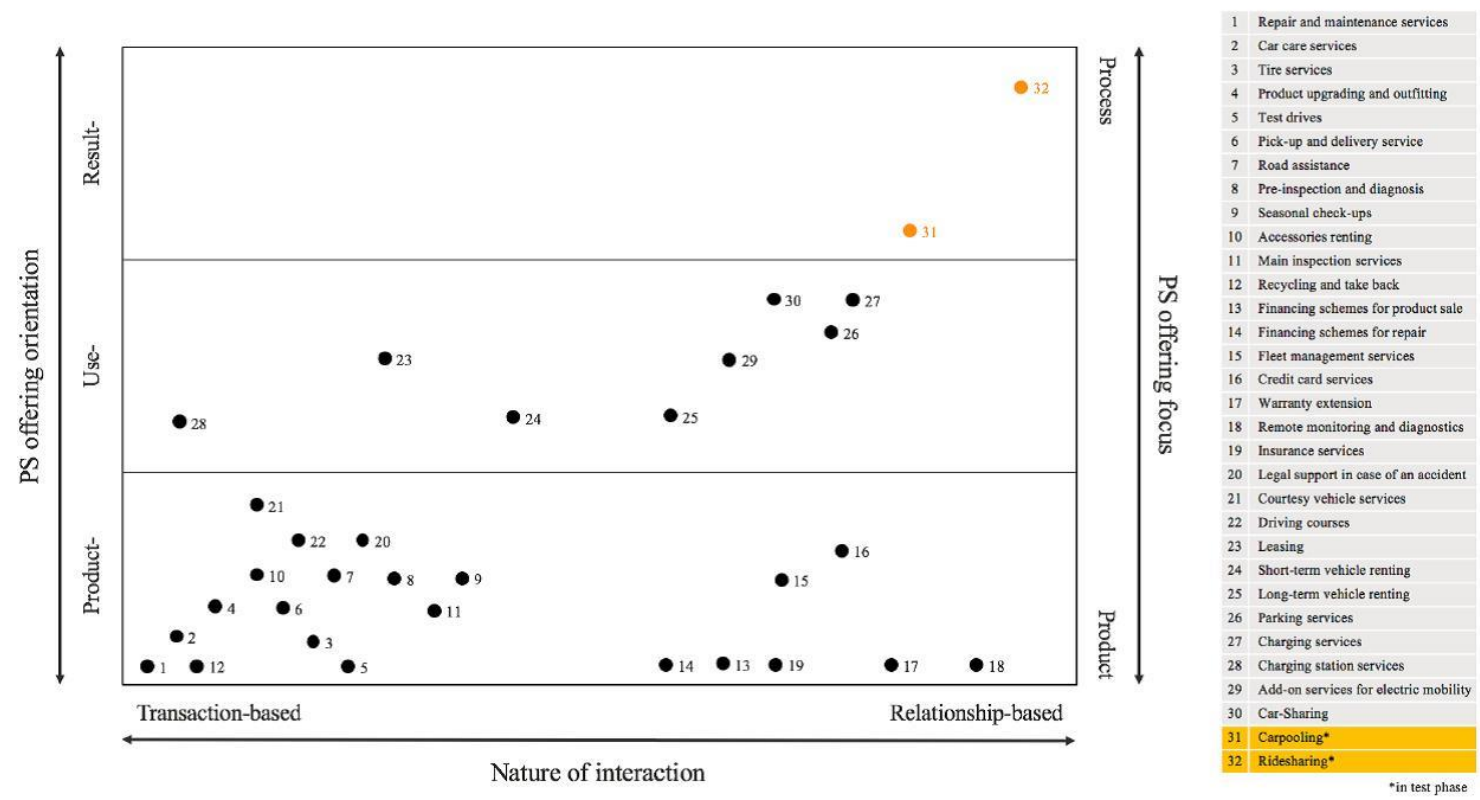

Figure 2. BMW's services orientation over time. Note that only 24 services are included, for which we were able to identify the year of introduction.
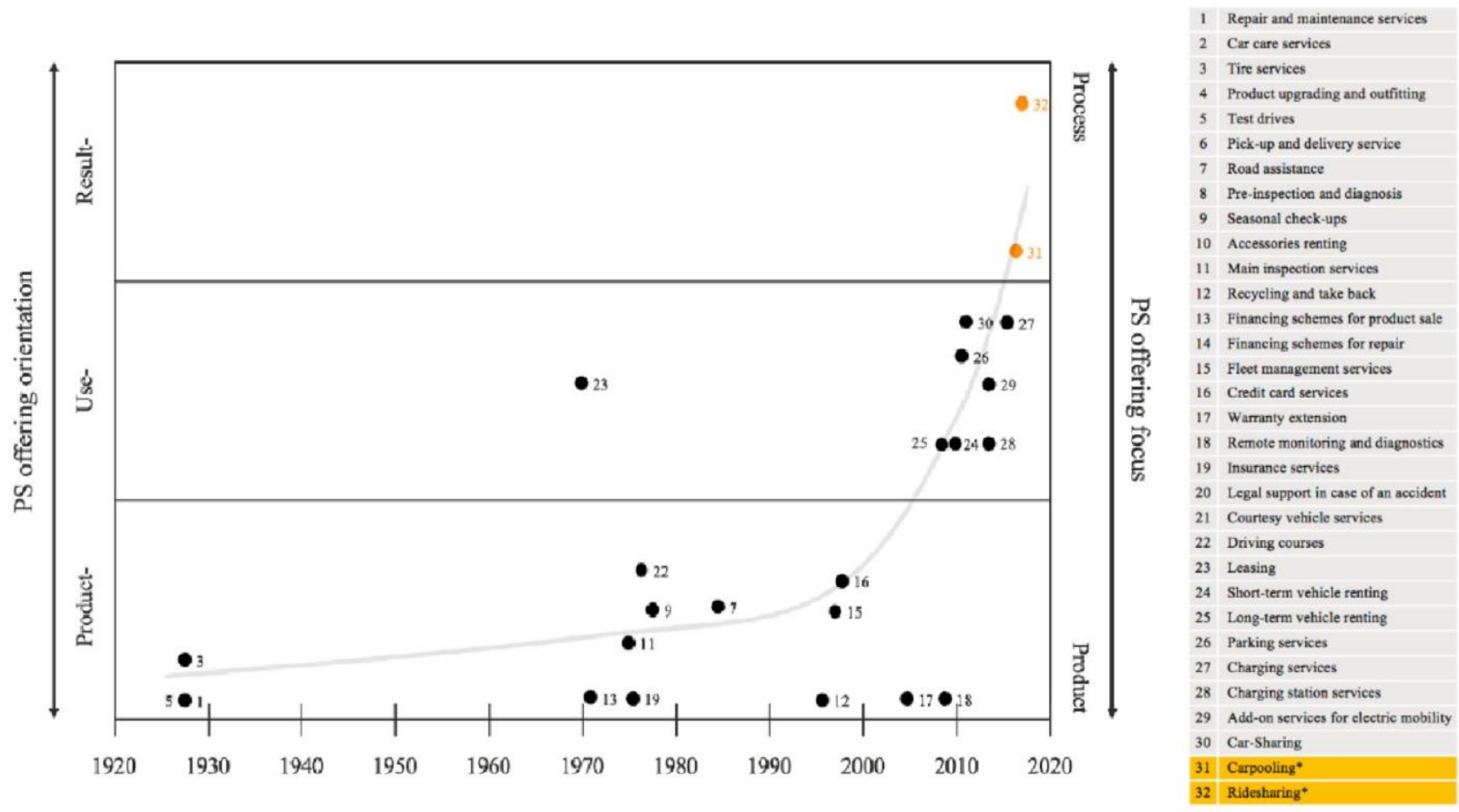
Figure 3. The servitization journey of a traditional car manufacturer.

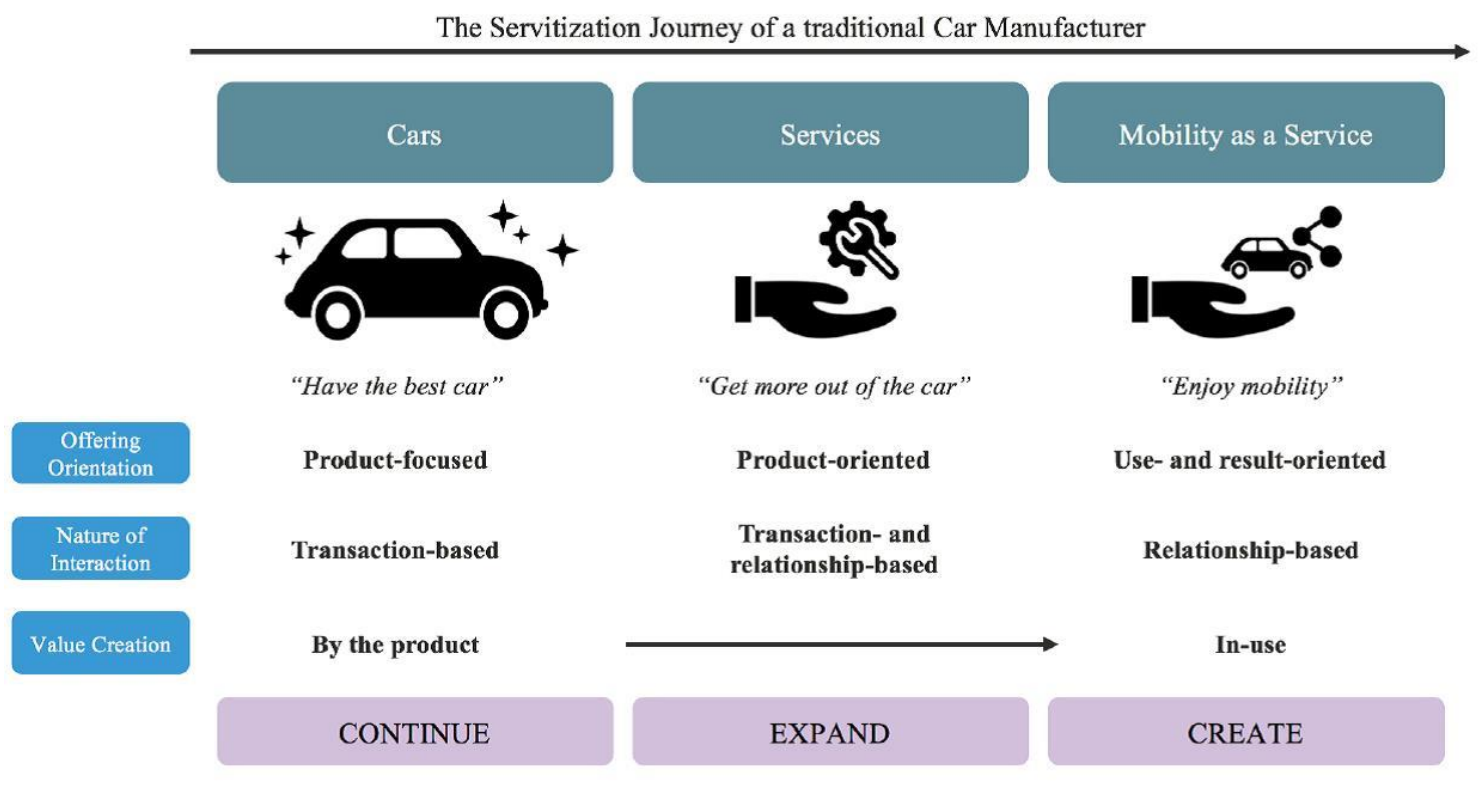

Figure 4. Findings matrix.

The Servitization Journey of a traditional Car Manufacturer

\begin{tabular}{|c|c|c|c|}
\hline \multicolumn{2}{|c|}{ Services } & \multicolumn{2}{|c|}{ Mobility as a Service } \\
\hline Opportunities & Challenges & Opportunities & Challenges \\
\hline $\begin{array}{l}\text { Increased interaction along } \\
\text { product lifecycle } \\
\text { - Lock-in effect of customers }\end{array}$ & $\begin{array}{l}\text { - Customer service satisfaction } \\
\text { - Intangibility and complexity of } \\
\text { services }\end{array}$ & $\begin{array}{l}\text { - Access to new customers } \\
\text { - Continuous interaction } \\
\text { - Push product sales } \\
\text { - More innovative brand image }\end{array}$ & $\begin{array}{ll}- & \text { New customer needs } \\
- & \text { Interpretation of premium } \\
- & \text { Rationality of relationship } \\
- & \text { Careless handling }\end{array}$ \\
\hline $\begin{array}{l}\text { Increased efficiency and } \\
\text { effectivity of interaction } \\
\text { More personal customer } \\
\text { relationship }\end{array}$ & $\begin{array}{l}\text { - Data transparency } \\
\text { - Effricient data management } \\
\text { - Disruptive innovations } \\
\text { - Extending servicc intervals }\end{array}$ & $\begin{array}{l}\text { - New innovative business } \\
\text { models } \\
\text { Learning capabilities for } \\
\text { continuous adaptation }\end{array}$ & $\begin{array}{ll}\text { - } & \text { Data transparency } \\
- & \text { New environment } \\
\text { - Shorter development eycles } \\
\text { - }\end{array}$ \\
\hline $\begin{array}{l}\text { Internal awareness of service } \\
\text { relevance }\end{array}$ & $\begin{array}{l}\text { - Need for consistent coaching of } \\
\text { sales personnel } \\
\text { - One-sided compensation }\end{array}$ & $\begin{array}{l}\text { Increased diversity of offering } \\
\text { - Overall growth }\end{array}$ & $\begin{array}{ll}\text { - Internal resistance } \\
\text { - } \\
\text { - Profor of cannibability of production sales }\end{array}$ \\
\hline $\begin{array}{l}\text { Trust in quality / brand } \\
\text { Warranties and leasing contracts } \\
\text { - Additional (comfort) services }\end{array}$ & - Relatively high prices & $\begin{array}{l}\text { - Existent need for vehicles } \\
\text { - Product expertise } \\
\text { - Financial capital }\end{array}$ & $\begin{array}{l}\text { - Agility of new entrants } \\
\text { - Lose of customer contact } \\
\text { - Risk of becoming supplier } \\
\text { - Partnerships with KIBS }\end{array}$ \\
\hline $\begin{array}{l}\text { High margins } \\
\text { High profit potential }\end{array}$ & $\begin{array}{l}\text { - Price-sensitivity of customers } \\
\text { - Rising costs of services } \\
\text { - Decreasing private ownership } \\
\text { - Rise of electric cars }\end{array}$ & $\begin{array}{l}\text { Increased quantity of customers } \\
\text { Expanded customer reach }\end{array}$ & $\begin{array}{l}\text { - Low revenues per customer } \\
\text { - Big up-front investment } \\
\text { - Poor infrastructure } \\
\text { - Risk of pay-per-use }\end{array}$ \\
\hline
\end{tabular}


Figure 5. Major changes to be expected along the servitization journey in the automotive industry.

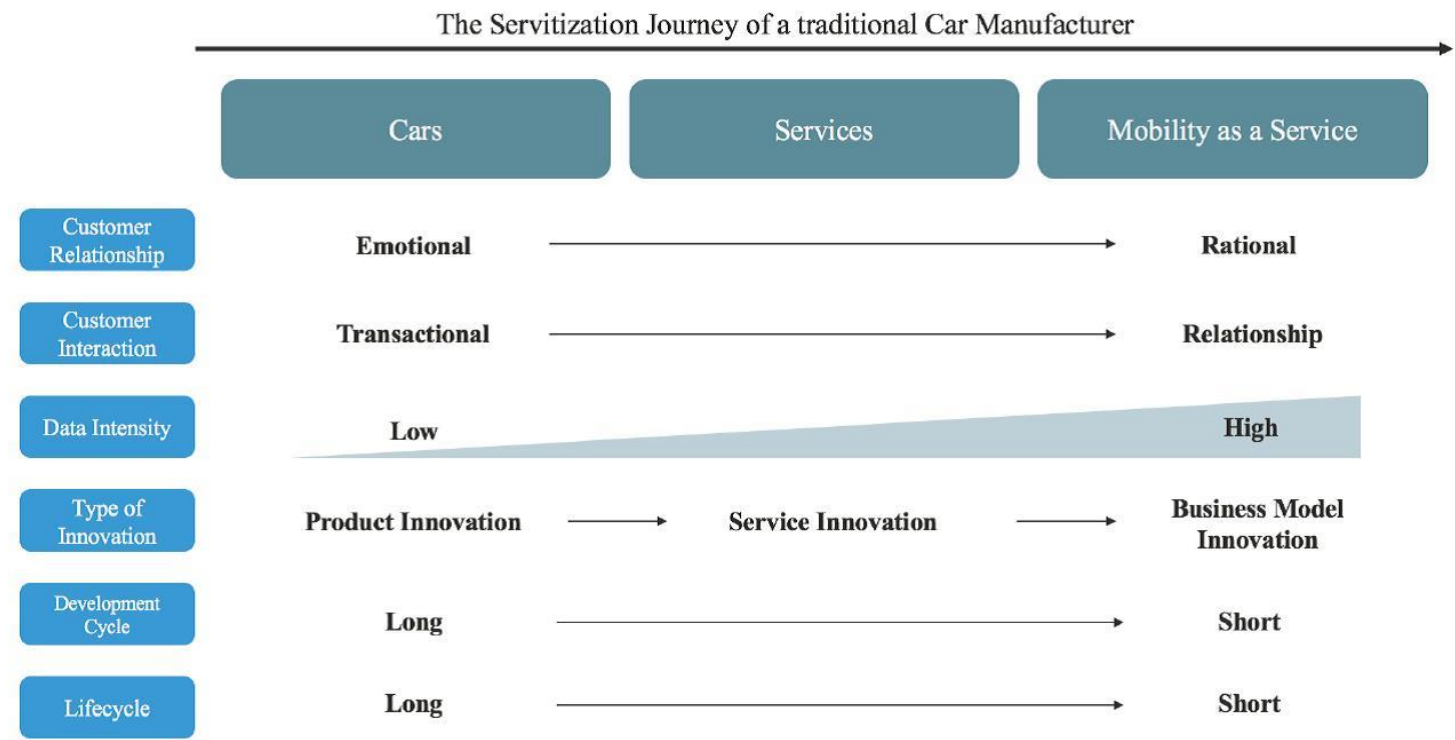

Table 1. List of the interviews, and interview details

\begin{tabular}{|l|l|l|r|l|}
\hline Shortcut & Respondent & Company & Date of Interview & Length of Interview \\
\hline BMW1 & Mobility Services Manager & BMW AG & 20.11 .17 & 47 minutes \\
\hline BMW2 & Mobility Services Manager & BMW AG & 03.12 .17 & 49 minutes \\
\hline Drive1 & Operations Manager & DriveNow GmbH & 20.11 .17 & 43 minutes \\
\hline Eng1 & Engineer Car Concept & BMW AG & 21.11 .17 & 10 minutes \\
\hline Dealer1 & Marketing Manager & BMW Euler Group & 25.11 .17 & 38 minutes \\
\hline Dealer2 & Sales Manager & BMW Euler Group & 02.12 .17 & 51 minutes \\
\hline
\end{tabular}

Table 2. Frequency distribution (and percentage) of BMW's services over classes.

\begin{tabular}{|l|c|c|}
\hline & $\begin{array}{c}\text { Transaction-based interaction } \\
\text { \#services (\% of total) }\end{array}$ & $\begin{array}{c}\text { Relationship-based interaction } \\
\text { \#services (\% of total) }\end{array}$ \\
\hline Product-orientation & $15(47 \%)$ & $7(22 \%)$ \\
\hline Use-orientation & \multicolumn{2}{|c|}{$8(25 \%)$} \\
\hline Result-orientation & \multicolumn{2}{|c|}{$2(6 \%)$} \\
\hline
\end{tabular}




\section{Biographical notes}

Felix Genzlinger is a consultant in the Operations \& Strategy Department of EY's Transaction Advisory Services, where he supports clients in the analysis and development of operating models as well as the study and interpretation of important key performance indicators to ensure their business sustainability in diverse industries like Automotive, Retail and Technology.

Leid Zejnilovic (Nova School of Business and Economics). His interests are in technology and innovation management, and organizational and societal changes in the face of technological changes.

Oscar F. Bustinza (University of Granada). His work aims to capture successful business servitization practices, analysing drivers of firm's boundaries choice and product-service innovation based upon data-driven analysis. 